УДК 656.073.23

\title{
ОЦІНКА ЕФЕКТИВНОСТІ РОУДРЕЙЛЕРНИХ ПЕРЕВЕЗЕНЬ
}

\author{
Д-р техн. наук А.М. Котенко, асп. О.О. Шапатіна, магістрант М.О. Воропай
}

ОЦЕНКА ЭФФЕКТИВНОСТИ РОУДРЕЙЛЕРНЫХ ПЕРЕВОЗОК

Д-р техн. наук А.Н. Котенко, асп. О.А. Шапатина, магистрант М.А. Воропай

\section{PERFORMANCE EVALUATION OF ROADRAILER TRANSPORT}

\section{Doctor of technical sciences A. M. Kotenko, graduate O.O. Shapatina, M.O. Voropai}

У статті обтрунтовується доцільність застосування роудрейлерних (бімодальних) перевезень в Україні. Запропоновано перевезення вантажів транспортними засобами, щяо обладнані змінною залізничною та автомобільною ходовою частиною (візками). Наведено математичні моделі організації технологій перевезень вантажів залізничним та роудрейлерним транспортом. Побудовано графи станів, на підставі яких складена система диференціальних рівнянь Колмогорова. Запропоновано економічну оцінку ефективності роудрейлерних перевезень.

Ключові слова: інтермодальні перевезення, роудрейлерні (бімодальні) перевезення, математичні моделі, графи станів.

B статье обосновывается иелесообразность применения роудрейлерных (бимодальных) перевозок в Украине. Предложень перевозки грузов транспортными средствами, оборудованными сменной железнодорожной и автомобильной ходовой частью (тележками). Приведены математические модели организации технологий перевозок грузов железнодорожным и роудрейлерным транспортом. Построены графы состояний, на основании которых составлена система дифференциальных уравнений Колмогорова. Предложена экономическая оченка эффективности роудрейлерных перевозок.

Ключевые слова: интермодальные перевозки, роудрейлерные (бимодальные) перевозки, математические модели, графы состояний.

In connection with the development of technologies that ensure compatibility with various modes of transport and railways with excellent standards in international transport of goods transit potential of Ukraine is not used in full. The article explains the usefulness of roadrailer (bimodal) transportation in Ukraine. Proposed freight vehicles equipped with a removable train and automobile chassis (bogies). It is possible to avoid major problems in the implementation of intermodal transport (including piggyback) - "dead weight" in the form of a moving car that always goes with the body of the car. The mathematical model of the organization of rail freight technologies and roadrailer trasport. Graphs of states, which is made on the basis of a system of differential equations of Kolmogorov. We propose an economic evaluation of roadrailer traffic.

Keywords: intermodal transport, roadrailer (bimodal) transport, mathematical models, state graphs.

Вступ. У зв'язку із недостатнім розвитком технологій, що мають забезпечувати сумісність різних видів транспорту, а також залізниць з відмінними
стандартами
при
міжнародних перевезеннях вантажів транзитний потенціал України використовується не в повній мірі. 
Постановка проблеми у загальному вигляді, iii зв'язок 3 важливими науковими та практичними завданнями. За останні роки інтермодальні перевезення знайшли широке застосування в країнах Європи. Розвитку такої нової форми транспорту сприяло, насамперед, об'єднання в одній системі найкращих якостей автомобільного та залізничного транспортів. Серед найкращих ознак автомобільного транспорту слід зазначити:

- еластичність, гнучкість, маневреність завдяки щільності автомобільних доріг і транспортних точок;

- можливість вибору маршрутів i схем доставки;

- можливість безпосередніх поставок вантажу з кожного місця відправки;

- підбір засобів транспорту залежно від категорії вантажу.

Що стосується залізничного транспорту, то тут слід було б відзначити:

- відносно низьку ціну перевезення на середні та дальні відстані;

- високу швидкість доставки на великі відстані;

- незалежність від кліматичних умов;

- значну частоту i регулярність сполучень.

Залізничний транспорт характеризує також меншу кількість пошкоджень вантажів, ніж автомобільний транспорт. Також має значення той факт, що залізничний транспорт, який реалізує сполучення на великі відстані, менше забруднює навколишнє середовище. До передумов щодо розвитку комбінованого транспорту слід ще додати зростаючі 3 кожним роком зменшення пропускної спроможності європейських автошляхів, а також порівняно довгий час очікування на кордонах $\mathrm{CC} 3$ іншими країнами Свропи. Враховуючи перераховані вище фактори, очевидним $\epsilon$ інтенсивний розвиток комбінованого транспорту в Свропі.

Аналіз останніх досліджень і публікацій. Питаннями удосконалення змішаних, комбінованих, інтермодальних перевезень у міжнародному сполученні займалися такі вчені: Аветикян М.А., Бутько Т.В., Гаджинський А.М., Галабурда В.Г., Данько М.І., Донченко А.В., Дьомін Ю.В., Загарій Г.I., Кірпа Г.М., Котенко А.М., Ломотько Д.В., Мироненко В.К., Миротин Л.Б., Мямлін С.В., Павленко А.П., Пшінько О.М., Савчук О.М., Тітов Н.Ф., Троцький М.В., Шибаєв О.Г., Яновський П.О. та інші вітчизняні та закордонні вчені $[1,2,3]$.

Метою статті $\epsilon$ обгрунтування доцільності застосування інтермодальних перевезень, зокрема, роудрейлерних.

Виклад основного матеріалу. У США та Канаді інтермодальні перевезення вантажів здійснюються більше 60 років. Донині їхній обсяг складає близько чверті перевезень, що виконуються залізничним транспортом. Зростає обсяг автомобільнозалізничних перевезень і в країнах Західної Європи. Особливо високими темпами розвиваються контрейлерні перевезення в міжнародному сполученні. Це явище $\epsilon$ результатом інтеграційних процесів, які інтенсивно поширюються Свропою [4].

Головні тенденції у вантажних перевезеннях на залізницях світу пов'язані 3 розширеним застосуванням спеціалізованого рухомого складу та збільшенням перевезень за змішаними схемами (контрейлерні та роудрейлерні перевезення) переважно в міжнародному сполученні. Інтермодальні перевезення, безумовно, один із найперспективніших напрямків розширення спектра транспортних послуг [5].

В статті розглянута доцільність перевезення вантажів транспортними засобами, що мають змінну залізничну та автомобільну ходову частини (візки) роудрейлерна технологія. При цьому можна уникнути основної проблеми при здійсненні інтермодальних перевезень (зокрема, контрейлерних) - «мертвої ваги» у вигляді автомобільної рухомої частини, що постійно прямує з кузовом вагона.

Розглянемо математичну модель технології перевезень вантажів залізничним 
та роудрейлерним транспортом. Для цього побудуємо графи станів та складемо систему диференціальних рівнянь Колмогорова. На підставі цих математичних моделей роудрейлерного та залізничного поїзда визначимо методику ефективності їх застосування.
Модель організації технології перевезень вантажів роудрейлерними поїздами можна подати у вигляді рис. 1. Математичну модель роудрейлерного поїзда подамо у вигляді графа станів (рис. 2).

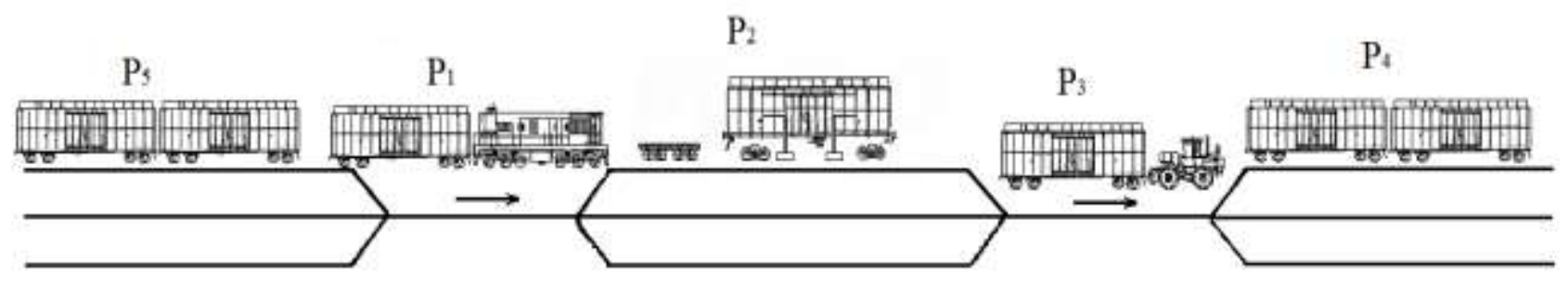

Рис. 1. Організація руху роудрейлерного поїзда

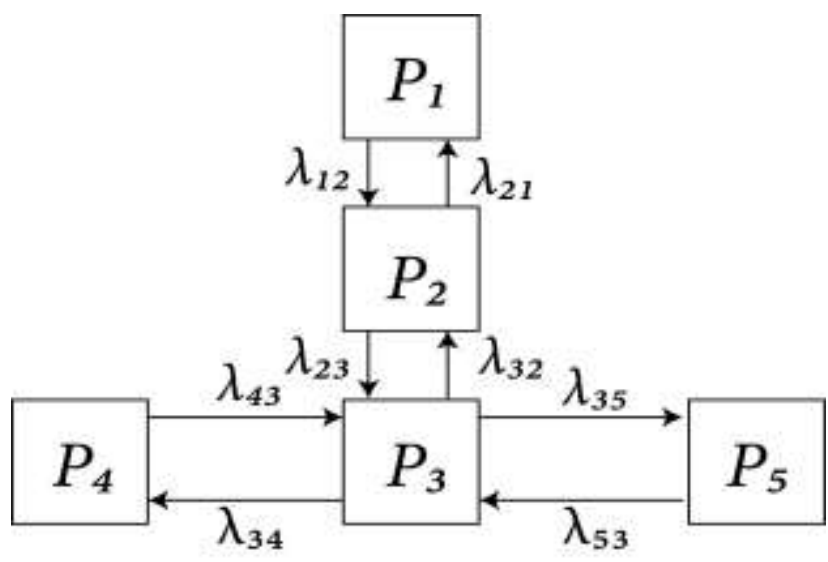

Рис. 2. Граф станів руху роудрейлерного поїзда

Згідно з графом станів (рис. 2) введені такі позначення:

$P_{1}$ - на шляху прямування до вантажної станції у складі вантажного поїзда;

$P_{2}$ - перевантаження залізничної рухомої частини на автомобільну та навпаки;

$P_{3}$ - на шляху прямування до вантажної станції у складі автомобільного вантажного модуля;

$P_{4}$ - знаходження під вантажними операціями у вантажоодержувача;
$P_{5}$ - знаходження під вантажними операціями у вантажовідправника;

$\lambda_{12}$ - інтенсивність переходу із стану прямування до вантажної станції у складі вантажного поїзда до стану перевантаження залізничної рухомої частини на автомобільну;

$\lambda_{21}$ - інтенсивність переходу із стану перевантаження автомобільної рухомої частини на залізничну до стану прямування до вантажної станції у складі вантажного поїзда; 
$\lambda_{23}$ - інтенсивність переходу із стану перевантаження залізничної рухомої частини на автомобільну до стану прямування до вантажної станції у складі автомобільного вантажного модуля;

$\lambda_{32}$ - інтенсивність переходу із стану прямування до вантажної станції у складі автомобільного вантажного модуля до стану перевантаження автомобільної рухомої частини на залізничну;

$\lambda_{34}$ - інтенсивність переходу із стану прямування до вантажної станції у складі автомобільного вантажного модуля до стану знаходження під вантажними операціями у вантажоодержувача;

$\lambda_{43}$ - інтенсивність переходу із стану знаходження під вантажними операціями у вантажоодержувача до стану прямування до вантажної станції у складі автомобільного вантажного модуля;

$\lambda_{35}$ - інтенсивність переходу із стану прямування до вантажної станції у складі автомобільного вантажного модуля до стану знаходження під вантажними операціями у вантажовідправника;

$\lambda_{53}$ - інтенсивність переходу із стану знаходження під вантажними операціями у вантажовідправника до стану прямування до вантажної станції у складі автомобільного вантажного модуля.

Оскільки потік заявок для роудрейлерних перевезень задовольняє три умови: відсутність післядії, стаціонарність та ординарність [6], тоді система диференціальних рівнянь Колмогорова для наведеного графа (рис. 2) запишеться у виразі

$$
\left\{\begin{array}{l}
\frac{d P_{1}}{d t}=\lambda_{21} P_{2}-\lambda_{12} P_{1} \\
\frac{d P_{2}}{d t}=\lambda_{32} P_{3}+\lambda_{12} P_{1}-P_{2}\left(\lambda_{21}+\lambda_{23}\right) \\
\frac{d P_{3}}{d t}=\lambda_{23} P_{2}+\lambda_{53} P_{5}+\lambda_{43} P_{4}-P_{3}\left(\lambda_{32}+\lambda_{35}+\lambda_{34}\right) \\
\frac{d P_{4}}{d t}=\lambda_{34} P_{3}-\lambda_{43} P_{4} \\
\frac{d P_{5}}{d t}=\lambda_{35} P_{3}-\lambda_{53} P_{5}
\end{array}\right.
$$

Нормувальна умова

$$
P_{1}+P_{2}+P_{3}+P_{4}+P_{5}=1 \text {. }
$$

За допомогою програмного забезпечення кафедри УЕР виконані розрахунки імовірності для граничних значень інтенсивності $\lambda$.
На підставі цього імовірності станів роудрейлерних перевезень в стаціонарному режимі наведені на рис. 3 .

Модель організації технології перевезень вантажного поїзда також

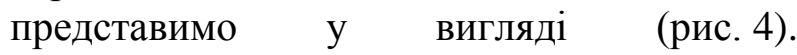
Математичну модель вантажного поїзда представимо у вигляді графа станів (рис. 5). 


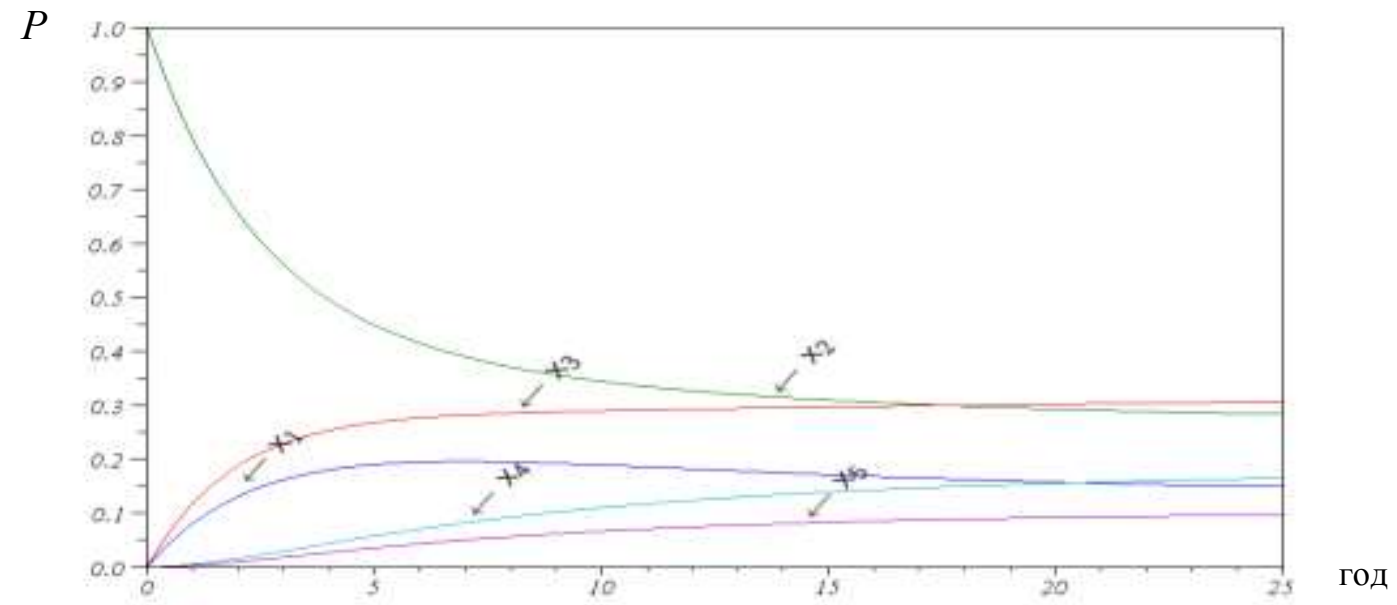

Рис. 3. Імовірності станів роудрейлерних перевезень в стаціонарному режимі

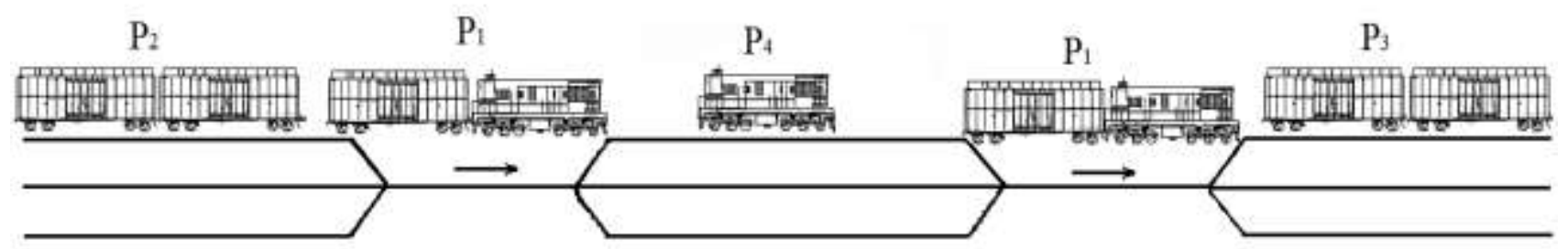

Рис. 4. Організація руху вантажного поїзда

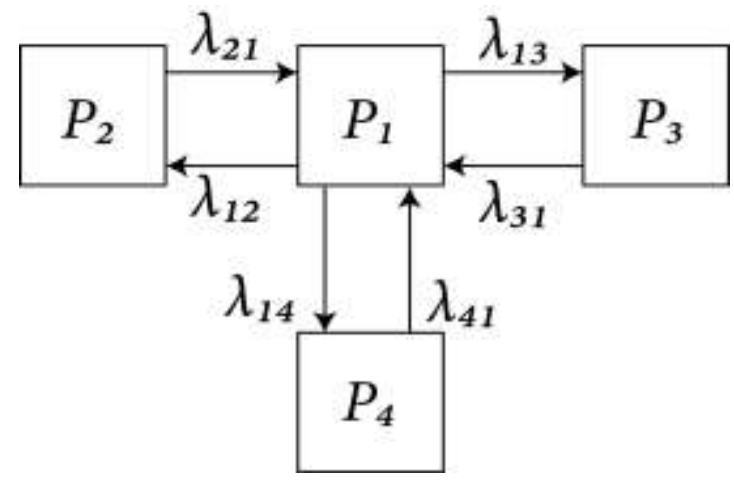

Рис. 5. Граф станів руху вантажного поїзда

Згідно з графом станів (рис. 5) введені такі позначення:

$P_{1}$ - на шляху прямування до вантажної станції;

$P_{2}$ - знаходження під вантажними операціями на станції відправлення;
$P_{3}$ - знаходження під вантажними операціями на станції призначення;

$P_{4}$ - обслуговування на технічній станції; 
$\lambda_{12}$ - інтенсивність переходу із стану прямування до вантажної станції до стану знаходження під вантажними операціями на станції відправлення;

$\lambda_{21}$ - інтенсивність переходу із стану знаходження під вантажними операціями на станції відправлення до стану прямування до вантажної станції;

$\lambda_{13}$ - інтенсивність переходу із стану прямування до вантажної станції до стану знаходження під вантажними операціями на станції призначення; $\lambda_{31}$ - інтенсивність переходу із стану знаходження під вантажними операціями на станції призначення до стану прямування до вантажної станції;

$\lambda_{14}$ - інтенсивність переходу із стану прямування до вантажної станції до стану обслуговування на технічній станції;

$\lambda_{41}$ - інтенсивність переходу із стану обслуговування на технічній станції до стану прямування до вантажної станції.

Аналогічно система диференціальних рівнянь Колмогорова для наведеного графа (рис. 5) запишеться у виразі

$$
\left\{\begin{array}{l}
\frac{d P_{1}}{d t}=\lambda_{31} P_{3}+\lambda_{21} P_{2}+\lambda_{41} P_{4}-P_{1}\left(\lambda_{13}+\lambda_{14}+\lambda_{12}\right) \\
\frac{d P_{2}}{d t}=\lambda_{12} P_{1}-\lambda_{21} P_{2} \\
\frac{d P_{3}}{d t}=\lambda_{13} P_{1}-\lambda_{31} P_{3} \\
\frac{d P_{4}}{d t}=\lambda_{14} P_{1}-\lambda_{41} P_{4}
\end{array},\right.
$$

Нормувальна умова

$$
P_{1}+P_{2}+P_{3}+P_{4}=1 \text {. }
$$

Імовірності станів перевезень вантажного поїзда в стаціонарному режимі наведені на рис. 6.

Цільова функція ефективності використання кожної 3 технологій перевезень має такий вигляд:

$$
C_{m p}=\sum\left(C_{i} P_{i}\right) \rightarrow \min ,
$$

де $C_{i}$ - відповідні експлуатаційні витрати;

$P_{i}$ - імовірності $i$-станів перевезень.

Тоді цільова функція при роудрейлерній технології перевезень може бути визначена (згідно зі стаціонарним режимом на рис. 3)

$$
C_{\text {poyd }}=0,15 C_{1}+0,3 C_{2}+0,3 C_{3}+0,15 C_{4}+0,1 C_{5} \rightarrow \min ,
$$

де $C_{1}$ - експлуатаційні витрати на транспортування вантажів у складі вантажного поїзда, грн;
$C_{2}$ - експлуатаційні витрати, що пов'язані із перевантаженням залізничної 


\section{Експлуатація залізниць}

рухомої частини на автомобільну та навпаки, грн;

$C_{3}$ - експлуатаційні витрати на транспортування вантажів у складі автомобільного вантажного модуля, грн;
$C_{4}$ - експлуатаційні витрати, що пов'язані із виконанням вантажних операцій у вантажоодержувача, грн;

$C_{5}$ - експлуатаційні витрати, що пов'язані із виконанням вантажних операцій у вантажовідправника, грн.

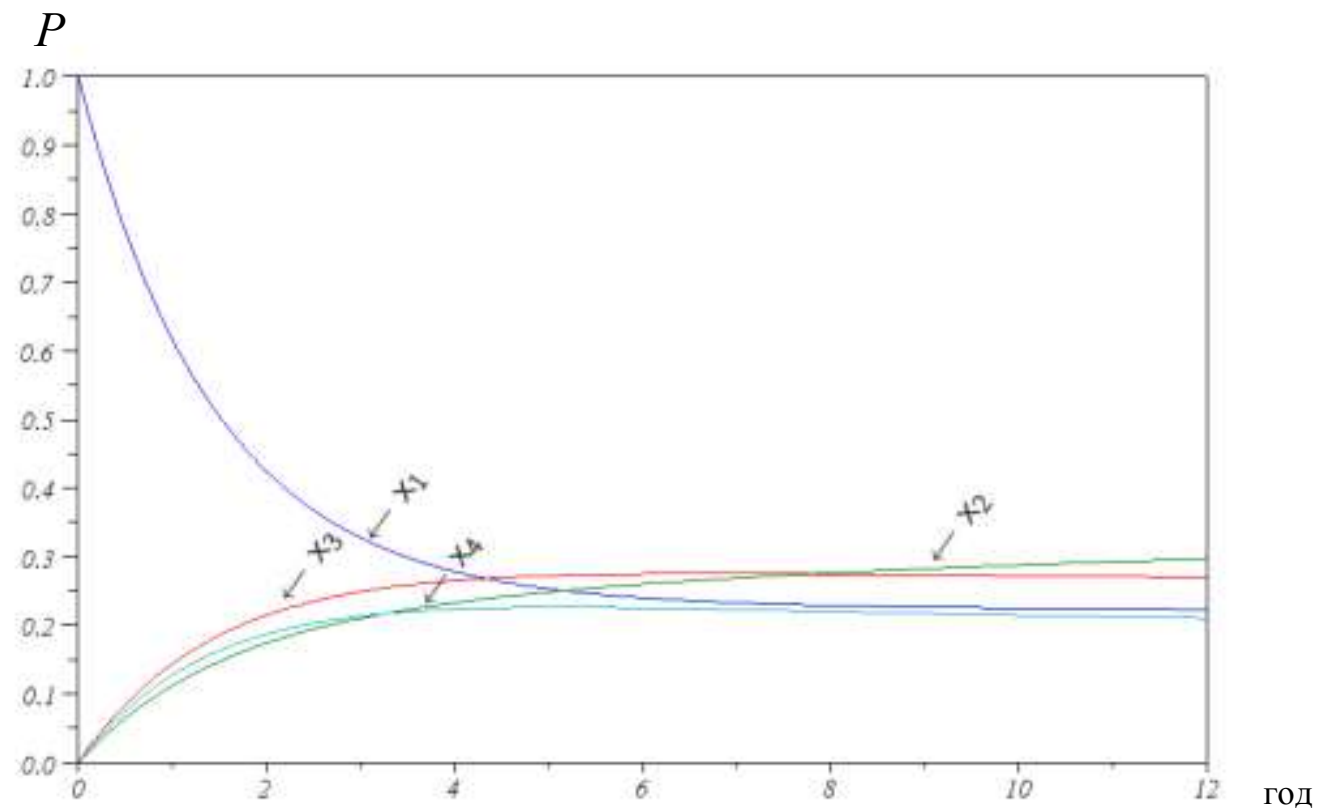

Рис. 6. Імовірності станів перевезень вантажного поїзда в стаціонарному режимі

Цільова функція при перевезенні у формулою (згідно зі стаціонарним вантажному поїзді визначається за режимом на рис. 6)

$$
\tilde{N}_{\hat{a} \grave{a} \grave{o}}=0,2 \tilde{N}_{6}+0,2 \tilde{N}_{7}+0,3 C_{8}+0,3 C_{9} \rightarrow \min ,
$$

де $C_{6}$ - експлуатаційні витрати на транспортування вантажів, грн;

$C_{7}$ - експлуатаційні витрати, що пов'язані із виконанням вантажних операцій на станції відправлення, грн;

$C_{8}$ - експлуатаційні витрати, що пов'язані із виконанням вантажних операцій на станції призначення, грн;
$C_{9}$ - експлуатаційні витрати, що пов'язані із обслуговуванням на технічній станції, грн.

Ефективність запровадження роудрейлерної технології може бути визначена таким чином 3 урахуванням капітальних витрат на організацію руху:

$$
\Delta E=\sum\left(C_{\text {poyd }} \cdot N_{i}\right)-\sum K
$$




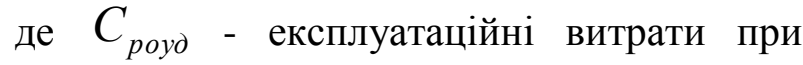
роудрейлерних перевезеннях вантажів, грн; $N_{i}$ - загальна кількість транспортних одиниць, що знаходяться в оберті, од.;

$K$ - капітальні витрати, що пов'язані 3 утриманням терміналів для організації роудрейлерних перевезень, грн.

\section{Висновки}

1. Спосіб перевезення вантажів транспортними засобами, що мають змінну залізничну та автомобільну ходову частини (візки), - роудрейлерна технологія дозволяє уникнути основної проблеми при здійсненні інтермодальних перевезень «мертвої ваги» у вигляді автомобільної рухомої частини, що постійно прямує 3 кузовом вагона.

2. На підставі математичної моделі організації технології перевезень вантажів роудрейлерним поїздом, що подана у вигляді графу станів та рішення систем диференційних рівнянь, можливо моделювати граничні зони їх ефективності.

3. У свою чергу, застосування роудрейлерної технології перевезень дозволить значно зменшити транспортні витрати, що пов'язані 3 перевезенням, знаходженням під вантажними та іншими операціями шляхом моделювання інтенсивностей станів організації перевезень.

\section{Список використаних джерел}

1. Котенко, А.М. Підвищення ефективності комбінованих перевезень. Удосконалення вантажної і комерційної роботи на залізницях України [Текст] / А.М. Котенко, В.Г. Кушнірчук // Зб.наук.праць. - Харків: УкрДАЗТ, 2004. - Вип. 62. - С.50-55.

2. Костюк, М.Д. Техніко-технологічне забезпечення інтермодальних та інтероперабельних перевезень [Текст] / М.Д. Костюк, Ю.В Дьомін // Залізничний транспорт України. - 2009. - №3. - С.3-7.

3. Матюшин, Л.Н. Комбинированные перевозки - технология будущего [Текст] / Л.Н. Матюшин, Б.Н. Стрекалов // Вестник ВНИИЖТ. - 1998. - №3. - С.28-32.

4. Кирпа, Г.Н. О возможных путях развития комбинированных перевозок грузов на Украине [Текст] / Г.Н. Кирпа, Ю.В. Демин // Труды ЗНЦ ТАУ - Проектирование, производство и эксплуатация автотранспортных средств. - Львов, 1995. - Т. 2. - С.64-66.

5. Інтермодальні перевезення [Електронний ресурс]. - Режим доступу: http://uz.gov.ua/cargo_transportation/intermodal_transportation/.-Загол. з екрану.

6. Вентцель, Е.С. Исследование операций [Текст] / Е.С. Вентцель. - М.: Советское радио, 1972. - 552 с.

Котенко Анатолій Миколайович, д-р техн. наук, професор кафедри управління вантажною і комерційною роботою Української державної академії залізничного транспорту. Тел. (057) 730-10-85.

Шапатіна Ольга Олександрівна, асистент кафедри управління вантажною і комерційною роботою Української державної академії залізничного транспорту. Тел. (057) 730-10-85.

Воропай Максим Олександрович, магістрант 13-6-ОПУТм Української державної академії залізничного транспорту. Тел. (057) 730-10-85.

Kitten Anatoly PhD, professor the department management trucks and commercial work Ukraine State Academy of Railway Transport. Tel. (057) 730-10-85.

Shapatina Olga, assist. of management by commercial work Ukraine State Academy of Railway Transport. Tel. (057) 730-10-85.

Voropay Maksym, 13-6-OPUTm Ukraine State Academy of Railway Transport. Tel. (057) 730-10-85. 